\title{
Karanlık Suya Batan Kadın İmgesi: Ophelia-Toplumsal Cinsiyet Bağlamında Resim ve Fotoğraf Sanatında Delilik
}

Dr. Öğr. Üyesi İlkay Canan OKKALI

Trabzon Üniversitesi

GSF, Resim Bölümü

icanikli@gmail.com

ORCID: 0000-0003-1817-4060
Öğr. Gör. Derya Kilıç SARIKAYA

Çanakkale Onsekiz Mart Üniversitesi Ç. Sos. Bil. M.Y.O. Gör. Işit. Tek. Med. Yap. deryakilic79@gmail.com ORCID: 0000-0002-4044-703X

\begin{abstract}
Öz
Bu makale, Bałı düşünce tarihinde ve sanatında delilik ile kadın arasındaki ilişki üzerine gönderme yaparak başlar. Hamlet Ophelia' sının yorumlanması, toplumsal cinsiyet, kadının konumu ve edebiyat alanlarındaki söylemler içindeki önemi bağlamında ele alınarak Ophelia'nın resme ve fotoğrafa aktarımasında sanatçıların yaklaşımları incelenmiştir. Deli kadın fenomeni insanlık tarihiyle aynı yaştadır ve sanat tarihi boyunca bu görsel imgenin geçirdiği dönüşümler, kadına yönelik toplumsal tutumlarda ve kadına yüklenen görevlerle koşut ilerler. Ophelia gençliği, güzelliği ve masumiyetiyle olduğu kadar solgun yüzü, deliliği ve genç yaşta ölümüyle kutsal kadın kavramının edebiyattaki en yakın benzeri olduğu gibi tüm deli kadınların da duayeni sayılır. Shakespeare'in oyununda dolaylı olarak anlatılan Ophelia'nın ölüm sahnesi birçok şair, yazar gibi ressamların ve fotoğrafçıarın da ilgi odağı olur. John Everett Millais 1852 ' de yaptığı Ophelia resmi ile dönemi ve sonrasındaki sanatçılara ilham verir. Bu çalışma Ophelia özelinde deliliğin kadınlık durumu ile neden ve nasıl ilişkilendirildiğini analiz edecektir. Analizler, Ophelia'nın resme ve fotoğrafa aktarımasında sanatçıların yaklaşımlarına ve feminist kuramcıların argümanlarına dayanmaktadır.
\end{abstract}

Anahtar Kelimeler: ophelia, delilik, kadınlık rolü, john everet† millais, gregory crewdson

Okkalı, İ. C. ve Sarıkaya, D. K. (2020). Karanlık Suya Batan Kadın Imgesi: Ophelia-Toplumsal Cinsiyet Bağlamında Resim ve Fotoğraf Sanatında Delilik. ARTS: Artuklu Sanat ve Beşeri Bilimler Dergisi, 3, ss. 117-134. 


\title{
arts
}

Research Article

\section{Image of the Woman \\ Sinking Down the Dark Water: \\ Ophelia-Insanity in the Art of \\ Painting and Photography in the \\ Context of Gender in Society}

\begin{abstract}
This article starts with a reference to the relationship between insanity and women in Western history of thought and art. The interpretation of Hamlet's Ophelia is discussed within the context of gender, the status of women and its significance in the discourses of literature, and the approach of artists in depicting Ophelia in paintings and photography is analysed. Madwoman phenomenon is as old as the history of humanity, and the transformation of this visual image progresses in parallel with the societal attitude towards women and the role attributed to women. As Ophelia is the closest representative of the concept of the holy woman in literature with her youth, beauty and innocence as much as with her pale face, insanity and death at a young age, she is also considered to be the doyenne of all the madwomen. Ophelia's scene, which is indirectly depicted in Shakespeare's play, became a focus of interest for many painters and photographers as well as poets and authors. John Everett Millais inspires the artists of his time and beyond with the Ophelia painting he made in 1852. This study will analyse how and why insanity is associated with femininity, through the specific case of Ophelia. The analyses are based on the approach of the artists in depicting Ophelia in paintings and photographs, and the arguments of feminist theoreticians.
\end{abstract}

Keywords: ophelia, insanity, role of femininity, john everett millais, gregory crewdson 


\section{$\operatorname{arts}=$}

\section{Gíriş'}

Batı düşünce tarihinde ve sanatında delilik ile kadın arasındaki ilişki üzerinde sıklıkla durulur. Kadın ve delilik konusu üzerine yapılmış pek çok çalışmada delilik teşhisi konan kadın sayısının erkek sayısından çok daha fazla olduğu belirtilir. Women's Madness: Misogyny or Mental Ilness? (Kadınların Deliliği: Kadın Düşmanlığı mı, Akıl Hastalığı mı?) kitabının yazarı Jane M. Ussher yüzyıllar içinde oranın değişmediğini, ancak "on sekizinci ve on dokuzuncu yüzyılların 'histeri'sinden, yirmi ve yirmi birinci yüzyıllardaki 'nevrotik' ve ruhsal bozukluklara" teşhisin adının değiştiğini belirtir (Ussher, 2011 , s.1). Toplumsal cinsiyet kuramı, feminizm, psikanaliz, felsefe çalışmaları gibi alanlara odaklanmış bir araştırmacı, sanat tarihçi ve eleştirel kuramcı Kaja Silverman ve edebiyat eleştirmeni, feminist ve konularda yazar Elaine Showalter "kadın" ile "delilik" arasında özel bir birlik olduğunu ve bunun ancak toplumsal cinsiyet merkezli bir bakışla anlaşılacağını savunurlar (Kaup, 1993, s.10). Showalter da tıpkı Ussher gibi "hem delilik hem de kadınlık tanımının kültürel olarak yapılandırılmıs" olduğunu ve "bu ikisi arasındaki ilişkinin kültürel çerçeve içinde ele alınması gerektiğini" öne sürer (Showalter, 1980, s. 179). Ussher "deliliği tanımladığımızda, akıllı olmanın ne demek olduğunu, yahut daha spesifik olarak, 'iyi kadının' davranış sınılarını da tanımlamış oluruz" der (Ussher, 2011 , s. 7). Dolayısıyla deliliğin tanımı egemen söylem tarafından olur ve Ophelia'nın öyküsündeki egemen söylem, erkek-egemen söylemidir. Şöyle ki Ophelia oyunda sadece beş sahnede karşımıza çıkar ve bu sahnelerin çoğunda neredeyse dinleyici konumundadır; ancak hiçbir şeyden haberi olmayan sıradan bir dinleyici değildir. Sessizliği içinde yaşadıklarını değerlendirir. Nitekim sarf ettiği sözleri dikkate alındığında bunların aslında kendi sessizliğinin dışavurumu olduğu görülür. IV. perdede ise deli Ophelia olarak ilk belirtisini verir. Artık aklını yitirmiştir ama özgürdür Ophelia, delilik hali ona özgürlüğünü hediye etmiştir.

\section{YÖNTEM}

Bu araş̧ırma betimsel modele dayalı nitel bir araştırmadır. Araştırmada

1 Karanlık Suya Batan Kadın İmgesi: Ophelia Toplumsal Cinsiyet Bağlamında Resim ve Fotoğraf Sanatında Delilik" adlı sözlü bildiri, 04-05 Ekim 2018' de Dokuz Eylül Üniversitesi DEKAUM tarafından İzmir'de düzenlenen 2.Uluslararası Kadın Konferansı'nda sunulmuş ancak yayınlanmamıştır. (The verbal statement, was presented at 2nd Women's Congress, held in İzmir in between the dates 04-05.10.2018 by the Dokuz Eylul University, but not published thereafter.) 
literatür taraması yapılmış ve veri toplanmıştır. Veriler; yerli ve yabancı literatürden elde edilen temel nitelikli sanat tarihi kitapları ve konuyla ilgili makale ve tezlere ek olarak çevrimiçi dergilerden sağlanmıştır. Ophelia'nın kendini suya bırakarak intihar eden ve delilik halini betimleyen resim ve fotoğraf sanatındaki örnekler seçilerek konu delilik bağlamında incelenmiştir.

\section{Hamlet Oyunu ve Ophelia Karakterinin Incelenmesi}

Hamlet, Danimarka Prensi'dir. Kral olan babası, amcası Claudius tarafından öldürülür. Claudius yeni kral olur ve Hamlet'in annesi Gertrude ile evlenir. Böylece hem kardeşinin krallığını hem de eşini almıştır. Bir zamanlar Hamlet'in babasının olan her şey artık amcasınındır. Hamlet, annesine duyduğu kinin, öfkenin acısını oyun boyunca Ophelia'dan çıkarır. Annesine sahip olamamıs, onun yerine Ophelia'yı koymuştur fakat Ophelia'ya acı çektirmekten de geri kalmamışıı. Önceleri onu sevdiğini söyler fakat sonra inkâr eder. Hamlet'in Ophelia'ya kur yapması doğrudan ona duyduğu ilgiden kaynaklanmaz, sanki annesiyle ödeşmek için yarı bilinçli bir şekilde yapar. Bu ilgi tıpkı hayal kırıklığına uğramış ve gücenmiş aşığın daha istekli bir rakibin kollarına atılması gibidir (Jones, 2004, s. 68). Shakespeare, Ophelia'nın geçmişi ve diğer karakterlerle olan ilişkisi hakkında çok az bilgi verir; buna Ophelia'nın Hamlet'e olan ilgisi de dahildir. Oyunda bazen Hamlet tarafından bazen babası ve abisi bazen de toplumdaki eril karakterlerce Ophelia'yı tanımlayan atıfarda bulunulur. Toplumun kadına yüklediği tüm davranış kalıplarını Shakespeare Ophelia karakterine atfeder. Toplumun kadınlardan beklentisi yüzyıllardır değişmemiştir; kadın saf, bakire olmalıdır. Toplumda söz sahibi olması da bir erkeğin korumasında olmasıyla ilintilidir dolayısıyla ya bir erkeğin kızıdır ya da bir diğerinin eşidir. Bunun haricinde ise kadın, Shakespeare'in Hamlet'e söylettiği gibi manastıra gitmelidir. Burada geçen manastır kelimesi Elizabeth çağı argosunda genelev anlamına da gelir. Hamlet bu sözü kullanırken bilinçaltıyla hareket etmişse de Showalter Hamlet' in bilinçli olarak Ophelia'ya hakaret ettiğini düşünür (Showalter, 2004, s. 247). Hamlet Ophelia'ya bu hayatta ancak birinin eşi olarak var olabileceğini ya da manastıra girmesi gerektiğini söylerken aynı zamanda "Buzlar kadar el değmemiş, karlar gibi temiz olsan da iftiranın elinden kaçamayacaksın" diye de ekler (Shakespeare, 2007, s. 117). Ophelia iftiradan kurtulamaz ve manastır yerine ölümü seçer. Ophelia'nın 


\section{arts}

içinde bulunduğu durum ve tercihi ortaya birbirinden farklı ve yoruma açık şu soruları çıkarır. O halde Ophelia kimdir? Gerçekten deli midir? Neden Hamlet'in deliliği akıllı bir delilik olarak vurgulanırken Ophelia'nın deliliği şarkılar söyleyen ve saçma kelimeler kullanan bir kadın olarak tanımlanır? Aslında bir tek Ophelia yoktur birden fazla kişiliği ile Ophelia vardır. Ophelia oyunun başında ümit dolu bir karakterken oyun boyunca başına gelenlerle, etrafındaki diğer karakterlerin eylemleri ile deliliğe evrilen bir değişim gözlenir. Bu büyük değişimin ise göstergesi dil aracılığıyla gerçekleşir. Carol Thomas Neely'ye göre Shakespeare deliliği deliliğe Özgü bir dil yaratarak ortaya koyar (Neely, 1991, s. 323). Foucault'ya göre de "Dil, deliliğin ilk ve sonuncu yapısıdır. Onun kurucu biçimidir; deliliğin doğasını ilân ettiği devrelerin hepsi onun üzerinde temellenir" (Foucault, 2017, s.353). Ophelia, Hamlet tarafından ihanete uğradığı yönündeki duygularını müstehcen şarkıları söyleyene dek gizlemeye devam eder (Hapgood, 2004, s. 127). Gertrude Ophelia için "abuk subuk şeyler söylüyor", sadece "tutarsız sözler" diyerek Ophelia' nın deliliğini kelimeler ve dille ilişkilendirmiş olur (Showalter, 2004, s. 250).

Nitekim yazar Maurice Charney ve Hanna Charney'e göre lirik dil, cümlelerdeki yapısal bozukluklar ve dizginlenemeyen yaratıcılık aslında dayanılmaz olan sosyal baskıları kırma yollarından biridir. Delilik, akı başında olan kadınların bastırmak zorunda kaldıkları duygusal ve yaratıa gücü sahnede serbest bırakır böylece delilikleri sayesinde varlıklarını güçlü bir şekilde ortaya koyabilirler (Charney, 1977, s.459; Baş, 2018, s.104). Dolayısıyla Ophelia'ya konulan delilik teşhisi de üzerinde kurulan baskının bir aracıdır. Normal konuşma ve mantıklı/anlamlı cümleler kurma yetisini yitirdiği düşünülen ve akli cümleler kuramayan Ophelia, bu hali ile erkek egemen dilden bir şekilde sıyrılmayı başarır ve söylemek istediklerini şarkılarla özgürce dile getirir hale gelir (Karadağ, 2017, s. 27). Joan Montgomery Byles Ophelia'nın delirdikten sonra kendisiyle ilk defa gerçek bir diyaloğa girdiğini ve başkalarının onu dinlemeye başladığını ancak Ophelia'nın artık dinleyiciye dahi intiyacı olmadığını ifade eder (Dane, 1998, s. 419; Baş, 2018, s. 104-105). Feminist eleştirmenler Sandra Gilbert ile Susan Gubar ve Carol Thomas Neely'e göre artık Ophelia kendisidir, özgürdür, ataerkil sistemin kurbanı değildir ve güçlüdür.

Peki delirdikten sonra ne olur? Bu soru iki farklı yorumlu cevaba sahiptir. Birincisi Ophelia delirdikten sonra kendisini nehre bırakır başka bir yoruma göre nehir kenarında şarkı söyleyip çiçek toplarken suya düşer. Belki de ölmek istemez ama 


\section{$\operatorname{arts}=$}

düştüğü nehirde yaşamak için de çaba göstermez. Ophelia'nın intiharı babasının ölümünden sonra delirdiğine inananlar için farkında olmadan yaptığı bir eylem gibi algılanır (Shakespeare, 2007, s. 184). Çoğunlukla da babasının ölümünden ziyade Hamlet'in aşkından delirerek intihar ettiği düşüncesi hâkimdir. Hamlet oyununda kadını inceleyen makalesinde David Leverenz, Ophelia'nın intiharını "erkek dünyasında kadının sürgün edilişinin bir mikrokozmozu" olarak niteler (Leverenz, 1978; Showalter, 2004, s. 250). İçinde bulunduğu sisteme karşı bir başkaldırı olarak da okunabilir. Bu nedenle eylemi intihar gibi algılanmak istemez. Ophelia öldükten sonra da rolü devam eder, mezarının oyundaki önemi göz ardı edilemez. (Shakespeare, 2007, s. 198).

\section{Resimde ve Fotoğrafta Ophelia Betimlemeleri}

"Ölüm çok güzel olmalı, yumuşak, kahverengi toprakta yatmak, birinin başının üzerinde çimlerin dalgalanması, ve sessizliği dinlemek... Dünün olmaması, ve yarının olmaması. Zamanı unutmak, hayatı affetmek, barışta olmak..."

Sylvia Plath

Ophelia, Shakespeare'in (1564-1616) en sık betimlenen kadın kahramanlarından biridir. Oyunda yer aldığı sahneler fazla yer tutmasa da birçok sanatçıya ilham vermiştir. Bilinen ilk Ophelia betimi John Bell'e (1775-6) ait bir illüstrasyondur (Görsel 1). Bu resim, 1775-1776 tarihleri arasında basılan Bell's Edition of Shakespeare's Plays adlı kitapta yer alır (Pınarbaşı, 2003, s. 111). Bu resimde oyuncu model olarak kullanılmıştır ama giysileri ile Ophelia kimliği desteklenir. Masumluğunu simgeleyen beyaz elbisesi çiçeklerle süslenmiştir ve yine çiçeklerle süslü bir taç †akar. Ophelia'nın kendine yaptığı taçdaki bitkilerin bir anlamı vardır. Ophelia'nın tacında dört bitki bulunur: bunlardan biri yabani karanfil türüdür. Vefasızlığı simgeleyen bu bitki Ophelia'nın Hamlet'le gerçekleşmeyen düğünü için duyduğu üzüntüye işaret eder. Bir diğer bitki ise ısırgan otlarıdır. Ophelia'nın yaptığı hatalardan dolayı kendi 


\section{arts $=$}

kendisine verdiği bedensel bir cezadır. Aynı zamanda, kafasında bu dikensi otlarla İsa'yı andıır ve onun gibi başkalarının günahları yüzünden de acı çekerek ölür. Taçtaki papatyalar Ophelia'nın masumiyetini vurgular. Taçtaki bir diğer çiçek ise cinselliği çağrıştıran mor bir yabani orkide çeşidi olan "long purples"dır. (Tigner, 2012, 100,101;Bozer, 2019, s. 118).



Görsel 1. John Bell (1741-1831), Bell's Edition of Shakespeare's Plays (1775-76) (http://www. english.emory.edu/classes/Shakespeare_Illustrated/Ophelia.html)

Ophelia'nın ölümünde yaygın olan düşünce Hamlet'in aşkından delirerek intihar etmiş olduğudur. Showalter, Elizabeth döneminin (1558-1603) romantik aşk düşüncesinin Ophelia'yı saf genç âşık olarak yorumlanmasına, Freud'un (18561939) seksüel araştırmaları da onv erotomaniye kapılmış genç kız imgesi olarak yorumlanmasına neden olduğunu söyler (Showalter, 2004, 253; Pınarbaşı, 2003, 114). Aşkı yüzünden delirdiğini düşünmek, onun saf masum genç kız rolünü vurgular. Lea Merrit (1880), John Mortimer (1775), Henry Nelson O'Neil (1874), James Sant(1864?), Marcus Stone (1888), Dominico Tojetti'nin (1880) resimlerinde saf masum Ophelia imgesi devam eder. Jean Baptiste Bertrand (1873-6) Ophelia resminde kucağında çiçek yerine adeta küçük bir köpek tutar gibidir.

19. yüzyılın ilk yarısında Ophelia'nın masum imajı değişmeye başlar. Sanat tarihinin konuya başlangıç için en önemli eserlerinden biri Pre-rafaelist John Everet† Millais'nin 1851-1852'de yaptığı Ophelia resmidir (Görsel 2). Millais'nin bu eseri 
dönemi ve sonrasında sanatçılara ilham kaynağı olur. Son derece gerçekçi bir ölüm anı resmidir. Aynı zamanda boğulmuş Ophelia'yı gösteren ilk örneklerdendir (https:// www.tate.org.uk/art/artworks/millais-ophelia-n01506/story-ophelia). Carol Thomas Neely boğulmanın Ingiltere' de o dönem kadınların intihar etmek için kullandıkları en yaygın yöntem olduğunu ifade eder (Neely, 1991, s.327; Baş, 2018, s.96). Ophelia'nın ölümünde su çok önemlidir. Cam gibi parıldayan suyun başında şarkı söyleyen, başında çiçekler, bukleleri suya yayılmış, yavaş yavaş karanlık suya batan genç kız; kaza, gerçeklikten kopuş ve intihar iç içe geçer. Ophelia' da özellikle de suyun daveti, sudan gelen ölüm, suya teslimiyet önem kazanır. Ophelia'nın suya gömülmesinin, kendi hüznüne gömülen bu genç kız imgesinin, ağlayan kadının kendi gözyaşında boğulmasını hatırlattığını söyler filozof Bachelard (Bachelard, 1999, s. 82). Kraliçenin Ophelia'nın suya düşüşünü anlattığı dizelerde de Ophelia'nın aslında kurtulmak için çırpınmadığını hatta mutlu bir şekilde ölüme gittiğini anlarız (Shakespeare, 2007, s. 184).

(...) Çeşit çeşit çelenkler yapmış kıza orda, sarkan dallara çelenklerini asmaya çabalarken, hain bir dal kırılıvermiş, o da çiçekten andaçlarıyla birlikte ağlayan dereye kapılmış. Yanlara açılan etekleri, bir süre denizkızı gibi su yüzünde taşımış onu. Eski ezgilerden parçalar okuyormuş hep; başına gelenden habersiz gibiymiş. Suda hiç yabancilık çekmiyormuş, doğal ortamında gibiymiş sanki. Ama uzun sürememiş bu durum; Suyu içtikçe ağırlaşan giysileri, zavallı kızcağızı tatı nağmelerinden koparıp, ölümün balçığına çekmiş.

Oyundaki bu anlatım Millas'nin resmine de ilham vermiştir (Görsel 3). Millais bu resim için Rossetti'nin karısı Elisabeth Siddal'ı model olarak kullanır. Bu resim için Siddal saatlerce giyinik olarak su içinde kalır (Pınarbaşı, 2003, s. 112). Ophelia oyunda IV. perde V. sahnede kederli bir şekilde kızgınlıkla biberiye, hercai menekşeler, rezene, papatyalar ve menekşeler de dâhil olmak üzere çeşitli otlar ve çiçeklerin adlarını sayıklar ve simgesel anlamlarından bahseder (Shakespeare, 2007, s. 173). Ophelia'nın herkese kendi karakterini vurgulayan otlar ve çiçekler vermesi bitkilerin sağalııcı özellikleri hakkında bilgi sahibi olduğunu ve şifalı bitkileri tanıdığını gösterir (Tigner, 2012, s. 98). Ophelia' nın ölüm sahnesinde deçiçekler vardır. Kraliçe onun açık olan mezarının üzerine çiçekler serper. Çiçekler ve anlamları resimde de metinde olduğu kadar önemli yer tutar. Millais, ayrıca Ophelia'nın elbisesinin kapalıı̆̆ı ile Ophelia'nın iffetli olduğuna, Victorian stilindeki gümüş nakışlı çiçekli elbise ile sosyo- 
ekonomik gücüne gönderme yapar. Sanatçı Ophelia'nın bakışlarındaki ifade ile delilik ve ölüme geçiş anıyla bağlantı kurar.

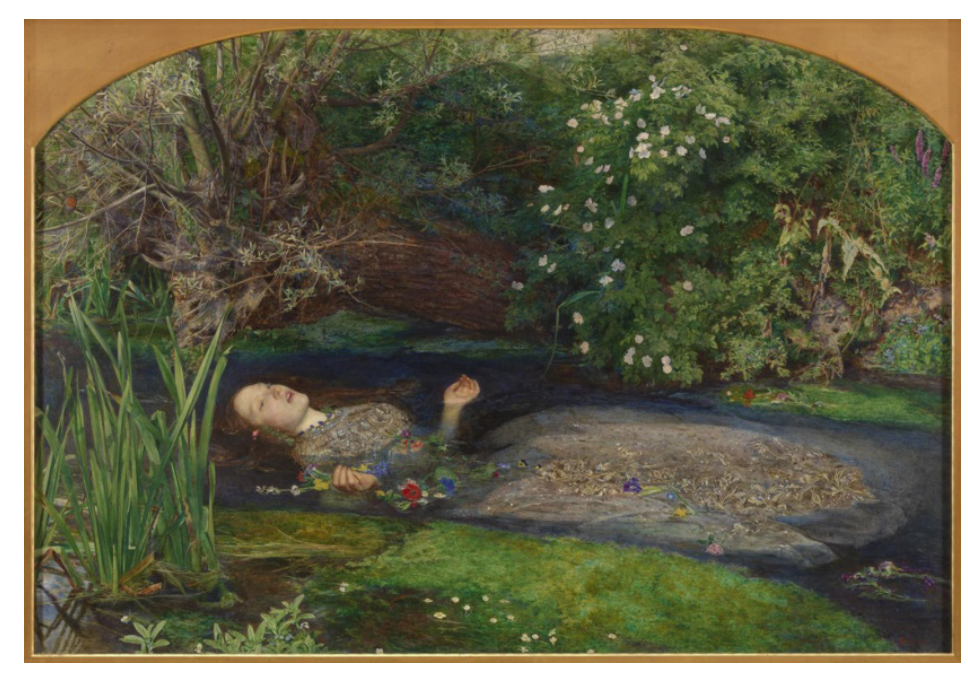

Görsel 2. Sir John Everett Millais, Ophelia, 1851-1852, $76 \mathrm{cmxl}, 12$ m, Tate Gallery. (https:// www.tate.org.uk/art/artworks/millais-ophelia-n01506)

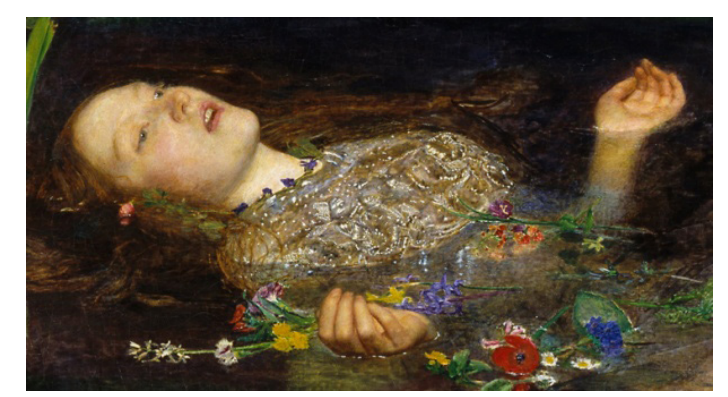

Görsel 3. Sir John Everett Millais, Ophelia, detay, 1851-1852, $76 \mathrm{cmx1,12} \mathrm{m,} \mathrm{Tate} \mathrm{Gallery.}$ (https://www.tate.org.uk/art/artworks/millais-ophelia-n01506)

Ophelia karakteri sahnelenirken genellikle beyaz renkle giydirilir, beyaz renk safığın ve temizliğin simgesidir. Rimbaud, Hugo, Musset, Mallarmé ve Laforgue gibi Fransız yazarlarına göre beyazlık Ophelia'nın doğal kadınlık sembolizminin bir parçasıdır. Feminist anlamda Ophelia'yı oynamanın yolunu açan ve sıra dışı olarak adledilen Ellen Terry ise 1878' de sahnelenen oyunda ilk kez siyah giyerek bu duruma itiraz etmiştir. Bu itiraz, oyunda sadece siyah giyen Hamlet'in varlığının karşısında Ophelia'nın varlığını güçlendirmiştir (Showalter, 2004, s. 260-261). Joseph Severn'in 
1831 tarihli Ophelia'sında da alışıldık beyaz giysi yerine koyu renkli bir giysi vardır (Görsel 4). Ophelia elinde Hamlet'in mektuplarından birini tutar ve kütüğün üzerinde çiçeklerden Hamlet yazısı okunur. Ophelia'nın bakışlarındaki ifade deliliğine vurgu yapar.

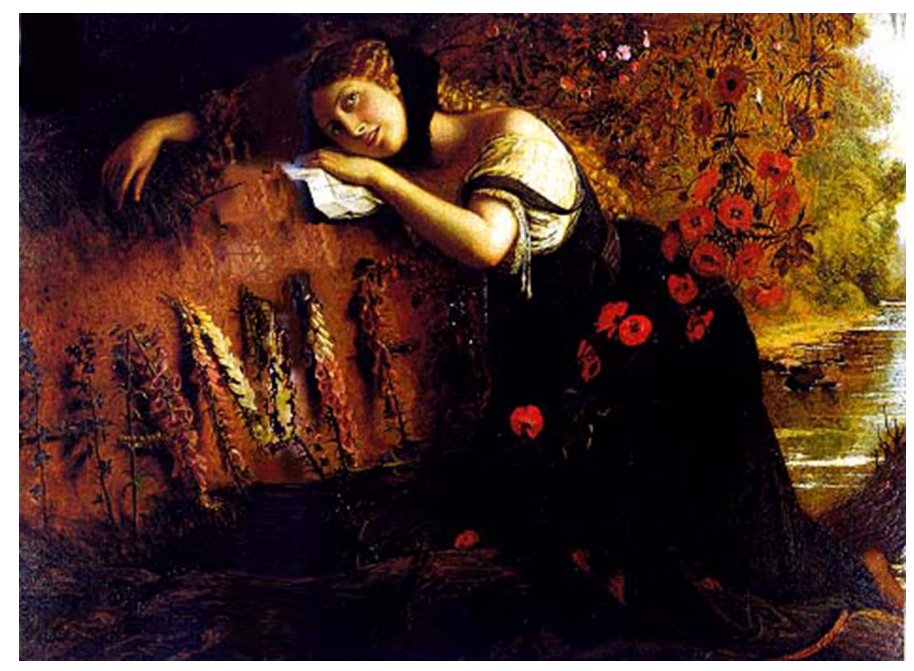

Görsel 4. Joseph Severn, Ophelia, 1831, tuval üzerine yağlıboya, 103x142,5 cm, özel koleksiyon (http://www.english.emory.edu/classes/Shakespeare_lllustrated/Severn.

Ophelia.html)

Tiyatroda 1827 yılında Harriet Smithson'un siyah duvakla girdiği sahneyle Ophelia'yı kadın cinselliği ve deliliği ile birlikte gösterme eğilimi başlar ve etkisi yüzyıldan fazla sürer. Smithson'un performansı resimde Eugène Delacroix'nın Ophelia'nın Ölümü resminde yakalanır (Showalter, 2004, s. 255-256). Sanatçı, Ophelia'yı bir dala tutunmuş olarak resmeder. Birazdan dal kırılacak ve Ophelia suya düşecektir. Delacroix, yaşamla ölüm arasında gerilim dolu sahneyi betimlemeyi tercih etmiştir (Görsel 5). Ophelia yaptığı tacı derenin kenarındaki söğüt ağacının eğilen dallarına takmak için ağaca tırmanırken ince dal onun ağırlığını taşımaz ve dalın kırılmasıyla suya düşer. Yaşadığı derin üzüntüler nedeniyle Ophelia kurtulmak için hiçbir çaba göstermez, kendini suya bırakır ve elbisesinin ağırlığıyla suya gömülür. Sanatçı erotik bir bakış açısı ile Ophelia'yı betimlemiştir. Bu bakış açısı dönemin sanat eserlerinde karşımıza çıkan ve kadını arzulayan erkeğin bakışı ile kadını arzu nesnesine indirger. 


\section{$\operatorname{arts}=$}

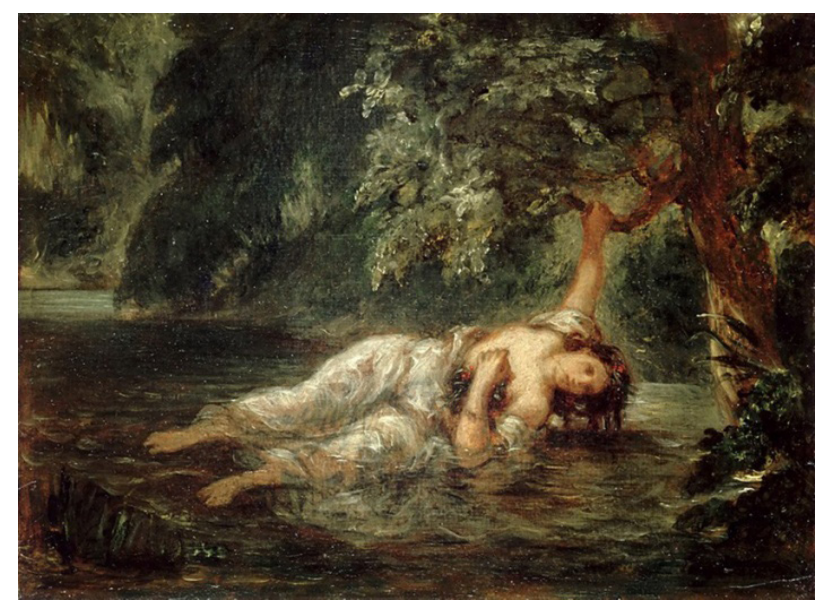

Görsel 5. Eugène Delacroix, Ophelia'nın Ölümü, 1853, tuval üzerine yağlıboya, 23x30cm, Louvre Müzesi (https://commons.wikimedia.org/wiki/File:Eug\%C3\%A8ne_Delacroix_-_La_ mort_d\%27Oph\%C3\%A9lie,_1853_(Louvre).jpg)

19. yüzyıl sonunda bazı resimlerde Ophelia doğruluğun kutsal simgesi olarak tasvir edilir. Bu resimler arasında Henrietta Rae'nin ve F.Littler'ın Ophelia'ları bulunur. Sarah Bernardt 1893'te Chicago Dünya Fuarı'nda Kadınlar Bölümü'nde Ophelia'nın bir yarım kabartmasını yapar (Showalter, 2004, 261). 20 yüzyılın başında John William Waterhouse, Ophelia'yı suya girmeden önce güçlü bir yüz ifadesi ve deliliğe özgü sabit bir bakışla betimler. Bu resimde Ophelia ne Hamlet tarafından sevilmeyi bekleyen ne de toplumun ona yüklediği değerlere uyan bir kadındır (Görsel 6). Ophelia'nın farklı iki karakteri bazen saf ve masum bazen güçlü ve tutkulu olarak değerlendirilmesine yol açarken aynı tezatık Ophelia'nın dağıttığı çiçeklere de yansır. Güçlü yüz ifadesi Georg Falkenberg'in çalışmasında da (1893) görülür (Görsel 7). Falkenberg'in Ophelia'sı tutkulu ve takıntılı bir kadının betimidir. Gözlerinin uykusuzluktan halkalanmış hali, gevşek çene ifadesi ve elinde çiçeklerle Ophelia'nın delilik halinin görselidir. 


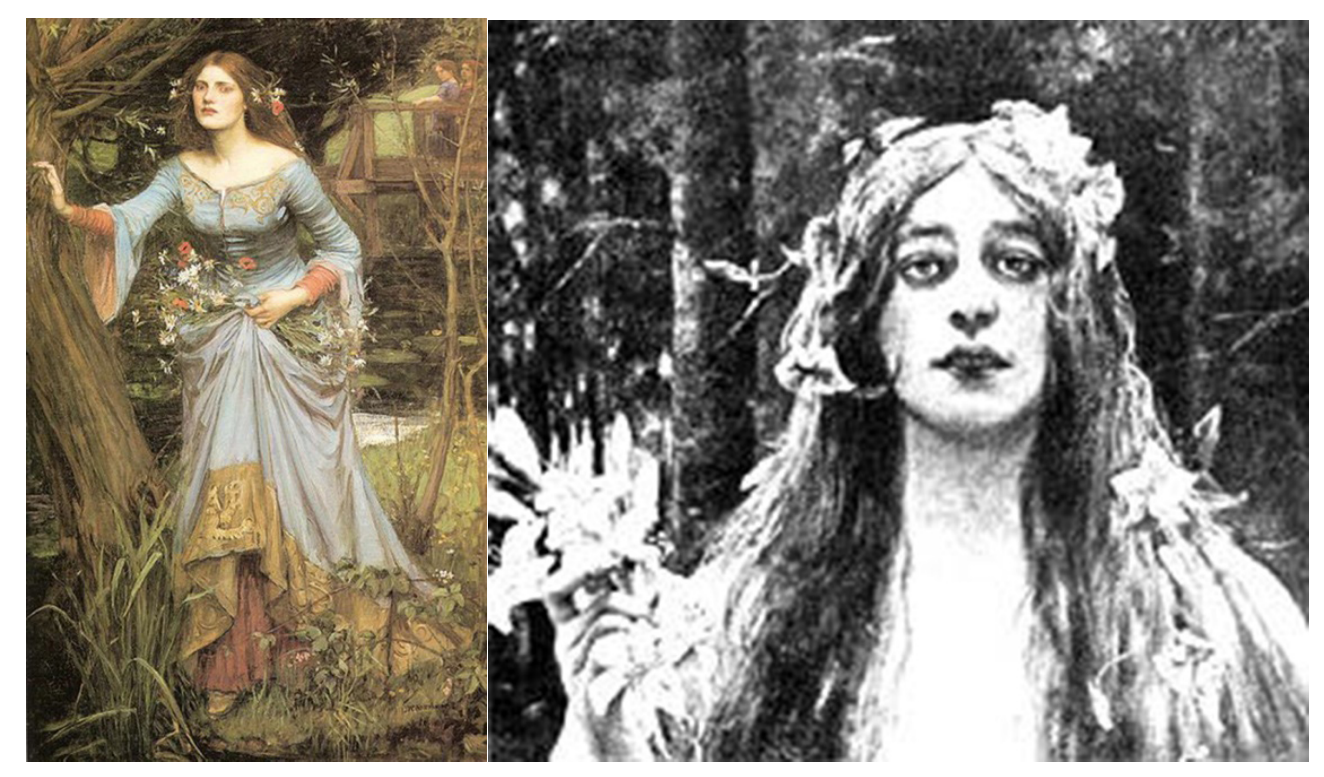

Görsel 6. John William Waterhouse, Ophelia,

1910, tuval üzerine yağlıboya, 62,2x 100,3 cm, özel koleksiyon (Andrew Lloyd Webber koleksiyonu).(https://commons.wikimedia.org/wiki/File:Ophelia_1910.jpg)

Görsel 7. Georg Falkenberg. Ophelia, 1898, özel koleksiyon.

(http://www.english.emory.edu/classes/Shakespeare_Illustrated/Falkenberg.Ophelia.html)

Geç 19. yüzyı tıp kitapları kadın hastalarla ilgili tartışmalarını Ophelia benzeri betimlemelerle görüntülenen genç kızların fotoğraflarıyla anlatır. Fotoğrafta Ophelia örnekleri ilk olarak Dr. Hugh Welch Diamond tarafından 1850'lerde Surrey tımarhanesi ve Bethlem'deki kadın hastalarını fotoğraflaması ile başlar (Görsel 8). Diamond hastalarını kamu akıl hastanesinin genellikle yoksul ve uzun vadeli sakinlerinden seçer. Fotoğrafta kadın hastaya siyah bir şal sarılarak, gözler bitkin, boş bir bakışla yan tarafta uzak bir noktaya kitlenmiş şekilde başının etrafına çiçekten bir taç yerleştirerek poz verdirilmiştir (Pearl, 2009, s. 9). Benzer bir çalışmayı Dr. Jean-Martin Charcot 1870'lerde Paris'teki La Salpêtrière hastanesinde tam teşekküllü bir stüdyo kurarak yapar. Kadın hastaları performansları için çalıştıır ve hipnoz alıında onlara Shakespeare'in kadın kahramanları oynamaları talimatı verir ve onları fotoğraflar 
(Showalter, 2004, s. 258). Deliliğin en önemli belirtilerinden biri olan boş ve sabit bakışlar fotoğrafta dikkat çeker.



Görsel 8. Dr. Hugh Diamond, Ophelia/Kadın hasta fotoğrafı, 1850'ler (http://www.english. emory.edu/classes/Shakespeare_Illustrated/Diamond.html)

1970'lerden itibaren Ophelia'nın deliliğini muhalif ve isyankâr olarak göstermeye dayanan yeni bir bakış açısı hakim olur. Bunda 1970'lerde yükselen feminist eleştiri ve sanat tarihinin feminist bakış açısıyla sorgulanması da etkili olur. 1971 'de Linda Nochlin'in Neden Hiç Büyük Kadın Sanatçı Yok?" başlıklı makalesinde soruyu yanıtlamaya çalışırken sanat tarihinde göz ardı edilmiş kadın sanatçılları gün yüzüne çıkarmayı amaçlar. (Peterson T.G., Mathews. P. 2010, s.14). Burada sorgulanan ise önemli soruların sorulma şeklinin dünya düzeni hakkında insanları nasıl koşullandırdığı hatta yanılgıya düşürdüğüdür. Bu bakış açısıyla birlikte birçok feminis† kuramcı Ophelia karakterini inceler ve bu kuramcılardan Showalter Ophelia'yı delikadın bir kahraman, aile ve toplumsal düzene karşı isyan eden güçlü bir kişilik ve ataerkil düzenin dilini konuşmayı reddeden, başka türlü konuşan histerik bir kız kardeş olarak yorumlar (Showalter, 2004, s. 264). Bu bağlamda John Everet† Millais'nin Ophelia eserinden öykünerek farklı bir dil yaratan Francesca Woodman'ın Untitled (Boulder 1976) eseri örnek verilebilir. Bu eser diğer Ophelia yapıtları arasında benzer bir atmosfer yaratarak aşinalık hissettirse de Woodman gri tonda mezarlık alanı içinde bir hayalet figürü gibi bir ağacın kökleri ile iç içe geçmiş olarak kendi vücudunu çıplak sahnelemiştir. Gücünü kendi bedeninden alan bu çalışma ile Woodman geleneksel kadın imajının nesneleştirilmesine karşı bir duruş yaratır. Geçmişte erkek 


\section{$\operatorname{arts}=$}

bakışı aracılığyla sunulan kadın imgelerinin edilginliği ve idealize edilmesi durumuna karşı çıkan bir anlatım yolu arar. Ataerkil düzeni eleştiren bir anlayışla gelenekseli ve "erkek sanatçı" anlayışını yıkmaya çalışır.

Fotoğraf icat edildiği zamandan bu güne sanat tarihinde her sanat akımıyla bir etkileşim içindedir. Modernizmden önce fotoğrafı belgeleme aracı olarak kullanma söz konusu iken, modernizmle birlikte fotoğraf bu yönünden sıyrılarak daha özgür ve soyut çalışmalar da yapılmaya başlanmışır. Fotoğraf sanatında üretilen Ophelia imgesinde aslında en çok edebiyattan etkilenildiği söylenebilir fakat kurgusu ve yorumlanmasıyla resim sanatından esinlenilir hatta alıntı yapılır. Fotoğrafçı Gregory Crewdson, Millais'nin resminden ilham alarak 2001 yllında çektiği İsimsiz (Ophelia) adlı fotoğrafı resimden farklı olarak gergin bir atmosfer yaratır (Görsel 9). Amerikan banliyösündeki bu evde çiçekler yoktur ama duvar kâğıdındaki çiçek sembolleri ile fotoğrafçı bu açığı kapatır ve Ophelia'yı Amerikan banliyösündeki kadının görseliyle 21. yüzyıla taşır. Gregory Crewdson, bu imgeye olan ilhamını şöyle anlatır: "Bu evde yaşamı boyunca yaşayan ve bu noktaya kadar gündelik bir varoluşa öncülük eden bir kadın. Merdivenlerden aşağı iner ve oturma odasını su basmış görür. Durumu kabul ederek kendini suya bırakır. Bu yüzden terlikleri merdivenlerde ve bornozları trabzandadır. Bunu, hem güzel hem de üzgün olan katarsis bir olay olarak görüyorum" (http://americaneighbourhood.blogspot.com/2010/11/ophelia.html).

Crewdson fotoğraflarını "geçiş anları" olarak tanımlar. Bu fotoğrafta da bir çok geçiş anını yakalamak mümkündür. Crewdson gündelik hayatını yaşayan normal bir kadının tükenmişliğe ve deliliğe geçişini, kendini suya bırakarak intiharıyla da ölüme geçişini belgeler. Ölüm ile deliliğin ortak noktası bir yere sabitlenmiş donuk bakışlar kadının yüz ifadesini güçlendirmiştir. 


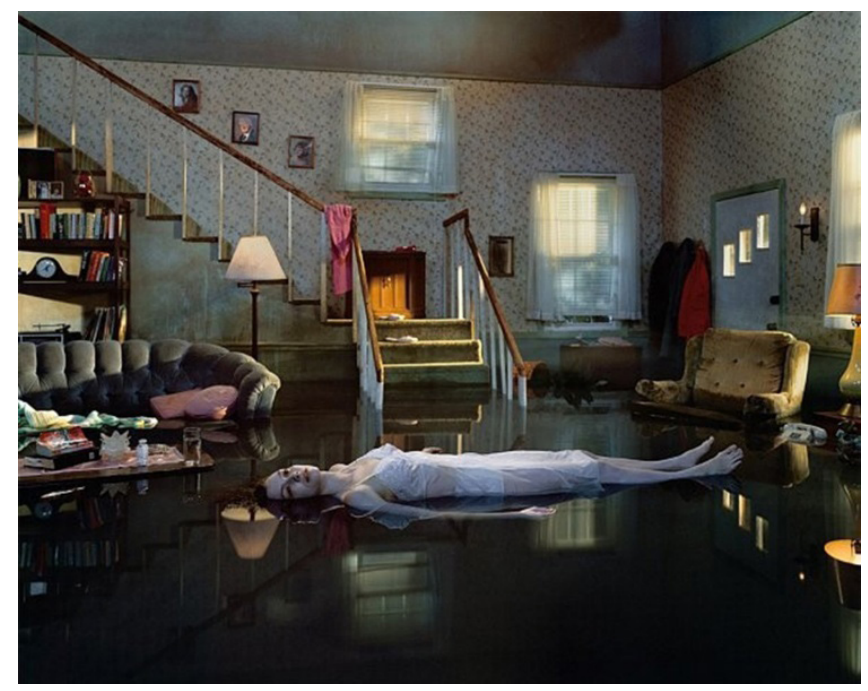

Görsel 9. Gregory Crewdson, İsimsiz (Ophelia), 2001, Digital baskı, 121,9x152,4 cm, 10 edisyon. (https://gagosian.com/exhibitions/2002/gregory-crewdson-twilight)

Claire Rosen'in Ophelia çalışmasında (Görsel 10) Ophelia'nın zengin görsel dili anında tanınabilir bir figür oluşturur. Suda yüzen, yeşillikler ve kurumuş yapraklarla çevrili beyaz bir elbise içindeki Ophelia yukarıdan bir bakışla çekilmiştir. Çalışma izleyicilere kendilerini hikâyenin içinde hayal etmelerine ve fotoğrafı bir masal olarak yorumlayabilmelerine ve gizli anlam arayışına davet eder. Saf ve masum Ophelia imgesinin devam niteliğindedir.

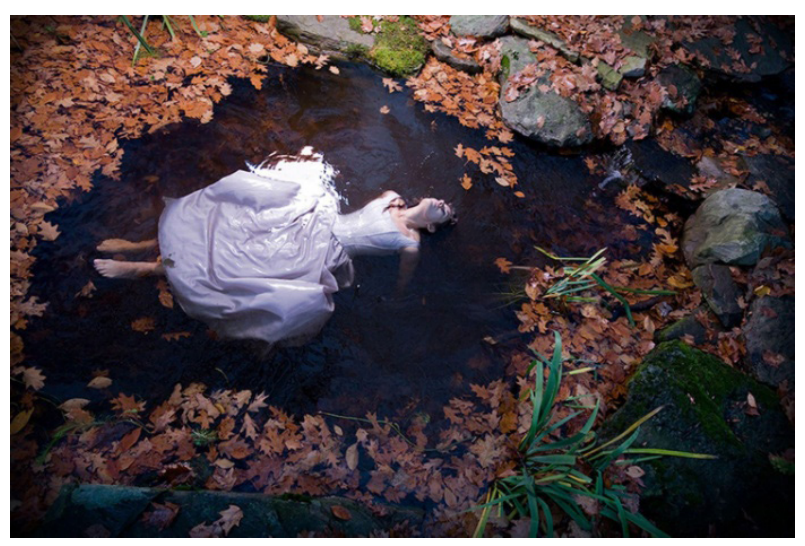

Görsel 10. Claire Rosen, Ophelia, 2008, Digital baskı. (https://www.clairerosenphoto.com/ fairy-tales-other-stories) 


\section{$\operatorname{arts}=$}

Karanlık Suya Batan Kadın İmgesi: Ophelia-Toplumsal Cinsiyet Bağlamında Resim ve Fotoğraf Sanatında Delilik

\section{SONUÇ}

Delilik ve kadın bağlamında Ophelia'yı inceleyen bu makalede çeşitli ressamların ve fotoğrafçıların çalışmalarından örnekler belirlenmiş ve Ophelia karakterinin sanatçılarca nasıl yorumlandığı incelenmiştir. Toplum yüzyıllardır geleneksel rolünü reddeden kadını sınırlarının dışına iterken, kadın da kendi sınırlarını genişletme intiyacı içinde olmuştur.

Nitekim John Berger'ın da belirttiği gibi "kadın olarak doğmak, erkeklerin mülkiyetinde olan özel, çevrelenmiş bir yerde doğmak demektir. Dolayısıyla kadınların toplumsal kişilikleri, böylesine sınırlı, böylesine koşullandırımış bir yerde yaşayabilme ustalıklarından dolayı gelişmiştir. Ne var ki bu, kadının öz varlığının ikiye bölünmesi pahasına olmuştur"(Berger, 1999, s.46). Ophelia karakteri de başta suskun, babasının ve abisinin sözünü dinleyen ataerkil yapının normlarına uygun bir karakterken üstüne geçirdiği delilik kılıfıyla sözünü esirgemeyen, krala bile cevap verebilen bir kadına dönüşür. Oyunda dil aracılığıyla gerçekleşen bu dönüşüm önce delilikle sonra ölümle biter. Shakespeare'in kurgusunda hayat bulan ve sonunda kazayla da olsa ölümü seçen Ophelia karakterindeki dönüşüm, aslında kadının görünürlük kazanmasının da dönüşümünü içerir. Ophelia'nın delilik ve ölümü resim ve fotoğraflarda sıklıkla işlenen konular arasında yer alırken deliliği çoğunlukla sabit ve donuk bakışlarla ifade edilmiştir. Ölümü ise suya batan kadın imgesiyle somutlaştırıır. Nitekim Pre-rafaelist John Everett Millais'nin 1851-1852 yıllarına tarihlenen Ophelia betimi bu konuda en etkileyici örneklerden biridir. Millais'nin betiminde oyunun tüm dramatizasyonu yansıtımış, ölüm anının gerçekçiliği resme aktarıımıştır.

Ayrıca John William Waterhouse ve Georg Falkenberg'in Ophelia betimleri de delilik ile güçlü bir şekilde ilişkilendirilen resimler olarak dikkat çeker. Söz konusu olan betimler erkek egemen söyleme aittir ve kadının varlığı eril sınırlar içerisindedir. Dolayısıyla Ophelia'nın resimsel varoluşu da deliliği ile vurgulanır. Ancak 21. yüzyılda fotoğraf sanatında Crewdson Ophelia'yı farklı bir söylemin içerisine alır ve Ophelia'yı bir ev kadınının isyanı olarak evinin içinde suya batmış bir şekilde fotoğraflar. Millais'nin resminden ilham alan bu çalışma, sıradan bir kadının özgürleşme yolu olarak delilik haline tutunmasıdır. Francesca Woodman'ın Untitled (Boulder 1976) eseri de Ophelia'nın deli-kadın bir kahraman olarak yorumlanması olarak dikkat çeker. Feminist sanatçılar temsili, kültürün kendi hakkındaki vizyonunu yansıtmasının 


\section{arts}

bir yolu olarak kavrarlar. Yani temsil, kültürdeki hakim ideolojiyi meşrulaştırır, önceden belirlenmiş toplumsal cinsiyet kavramlarını yeniden sunarak farkllığı inşa eder. (Peterson T.G., Mathews. P. 2010, s.37).

Hamlet'in akıllı deliliğine karşı Ophelia'nın aciz veya baştan çıkarıcı deliliği toplumsal cinsiyet bağlamında kadın ve deliliğe bakışın göstergesidir. Sonuç olarak tek bir Ophelia yoktur. Çoğu zaman temsildeki metnin dışına çıkarak sahnede, resimde ve fotoğrafta birbirinden farklı Ophelia'lar karşımıza çıkar; 19. ve 20. yüzyılın ressamlarının betimlerindeki erkeğe bağımlı ve nesne olarak gösterilen kadın ya da 21. yüzyılın toplumsal düzenine isyan eden kadın gibi farklı Ophelia temsilleri yer alır. 19. yüzyılda erkek bakış açısı ile yapılan eserlerde kadının nesne olarak gösterilmesine karşın 20. yüzyılda kendisi de feminisł olan Franceska Woodman gibi sanatçıların bakışı gibi toplumsal cinsiyet kavramlarını yeniden sunan çalışmalar farklı Ophelia temsilleridir. Bu yorumlamanın farklıı̆ı̆ aslında 21. yüzyılın toplum yapısının değişimi ve feminist söylemler ile kadının konumunun yeniden değerlendirilmesi ile ilintilidir.

\section{KAYNAKÇA}

Bachelard, G. (1999). Water and Dreams. The Pegasus Foundation.

Baş, E. (2018). Ophelia: Deliliğin Dili, Dilin Deliliği. Trakya Üniversitesi Edebiyat Fakültesi Dergisi, Cilt: 8 Sayı: 16, Temmuz 2018, s. 90-107.

Berger, J. (1999). Görme Biçimleri (Çev. Y. Salman). İstanbul: Metis Yayınları.

Bozer, D.A. (2019). Shakespeare'in Hamlet Oyununda Çürümüşlük ve Hastalık İzlekleri ve İmgeleri. Hacettepe Üniversitesi Edebiyat Fakültesi Dergisi, Haziran/June 2019 - 36(1), 110-121. doi: 10.32600/huefd.469147

Foucault, M. (2017). Deliliğin Tarihi (Çev: M. A Kilıçbay). 7.bs. Ankara: İmge Kitabevi.

Hapgood, R. (2004). Hamlet Nerdeyse Absürd: Ertelemenin Dramatürjisi (Çev: A. Çetiner). Mimesis Tiyatro/Çeviri ve Araştırma Dergisi Hamlet Özel Sayısı, S:10, İstanbul: Boğaziçi Üniversitesi Yayını. 117-131.

Jones, E. (2004). Hamlet'in Gizeminin Bir Açıklaması Olarak Oedipus Kompleksi: Güdüler Üzerine Bir Çalışma (Çev: B. Orak, A. Yıldıım, B. Yeldiren ). Mimesis Tiyatro/ Çeviri ve Araştırma Dergisi Hamlet Özel Sayısı, S:10, İstanbul: Boğaziçi Üniversitesi Yayını. 39-84. 


\section{$\operatorname{arts}=$}

Karadağ, Ö. (2017). Disiplinlerarası ve Medyalararası bir Yeniden Yazma Eylemi Olarak Metin ve Performans: Hamlet Makinesi (1977) \& "Ophelia'ya Ölüm Yakışı" (2005). Alman Dili ve Edebiyatı Dergisi-Studien zur deutschen Sprache und Literatur 2017/II. s.23-48. https://dergipark.org.tr/tr/download/article-file/394104

Kaup, M. (1993). Mad Intertextuality: Madness in Twentieth-Century Women's Writing. Trier: WVT Wissenschaftlicher Verlag Trier.

Leverenz, D. (1978). The Woman in Hamlet: An Interpersonal View. Signs, Vol. 4, No. 2 (Winter), pp. 291-308 https://www.jstor.org/stable/3173027? seq=2\#metadata_ info_tab_contents

Neely, C. (1991) Documents in Madness: Reading Madness and Gender in Shakespeare's Tragedies and Early Modern Culture. Shakespeare Quarterly, 42.3

Pearl S. (2009). Through a Mediated Mirror: The Photographic Physiognomy of Dr. Hugh Welch Diamond. History of Photography, 33(3):288-305.

Peterson T.G., Mathews. P. (2010). Sunuş Sanat Tarihinin Feminist Eleştirisi (Çev.E. Soğancılar). Sanat-Cinsiyet: Sanat Tarihi ve Feminist Eleştiri (Ed. A. Antmen), (2.bs), İstanbul: İletişim Yayınları, 13-117.

Pınarbaşı, S. Ö. (2003). Bałı Resminde Ophelia Betimleri. Sanat Tarihi Yıllığı, S.16, İstanbul: İstanbul Üniversitesi Yayını. s. 107-122.

Shakespeare W. (2007). Hamlet (Çev. B. Bozkurt). 9.basım, İstanbul: Remzi Kitabevi.

Showalter, E. (1980). Victorian Women and Insanity. Victorian Studies, 23/2, 157-181.

Showalter, E. (2004). Ophelia'nın Temsili: Kadınlar, Delilik ve Feminist Eleştirinin Sorumlulukları (Çev: Z. Okan-G. Tunç). Mimesis Tiyatro/Çeviri ve Araştırma Dergisi Hamlet Özel Sayısı, S:10, İstanbul: Boğaziçi Üniversitesi Yayını. 247-265.

Tigner, A. L. (2012). Literature and the Renaissance garden from Elizabeth I to Charles II. Londra ve New York: Routledge.

Ussher, J. M. (2011). The Madness of Women: Myth and Experience. London: Routledge.

http://americaneighbourhood.blogspot.com/2010/11/ophelia.html. Erişim Tarihi. 15.08.2018

https://www.tate.org.uk/art/artworks/millais-ophelia-n01506/story-ophelia Erişim Tarihi. 19.02.2020 